\title{
Effect of a supplement rich in linolenic acid added to the diet of post partum dairy cows on ovarian follicle growth, and milk and plasma fatty acid compositions
}

\author{
Andrew A. PONTER ${ }^{a *}$, Anne-Emmanuelle PARSY ${ }^{\mathrm{a}}$, Marion SAADÉ ${ }^{\mathrm{b}}$, \\ Jean-Paul MIALOT ${ }^{\mathrm{a}}$, Christine FiCHEUX ${ }^{\mathrm{a}}$, Christine DUVAUX-PONTER ${ }^{\mathrm{c}}$, \\ Bénédicte GRIMARD ${ }^{\mathrm{a}}$
a UMR INRA-ENVA 1198, Biologie du Développement et Reproduction, 7 avenue du Général-de-Gaulle, 94704 Maisons-Alfort, France
${ }^{\mathrm{b}}$ Ferme Expérimentale, Institut National Agronomique Paris-Grignon, 78850 Thivernal-Grignon, France
c UMR INRA-INA P-G, Physiologie de la Nutrition et Alimentation, \\ 16 rue Claude Bernard, 75231 Paris Cedex 05, France
}

(Received 20 December 2004; accepted 11 June 2005)

\begin{abstract}
The objective of this study was to determine the effect of a linseed supplement on follicle growth, progesterone concentrations and milk and plasma fatty acids in dairy cows post partum. Sixteen Holstein cows were given a basal total mixed diet plus one of two supplements: control (C; extruded soybeans; $n=8$ ) or linseed (L; extruded linseeds; $n=8$ ). One month after calving oestrous cycles were synchronised (PRID ${ }^{\circledR}$ ). Follicle growth and milk progesterone concentrations were measured every $2 \mathrm{~d}$ over the induced oestrous cycle. Milk production characteristics were unaffected by treatment. The L cows lost significantly more BCS than the C cows $(P<0.01)$. Plasma insulin, glucose and urea were unaffected by the treatment. Plasma NEFA tended to be affected by the treatment $(\mathrm{L}>\mathrm{C}, P=0.08)$. The proportions of $18: 3 \mathrm{n}-3$ in milk and plasma were increased by $\mathrm{L}$ compared to $\mathrm{C}(P<0.001$ and $P<0.01$, respectively). There was an effect of dietary supplement on the numbers of small follicles $(\mathrm{L}<\mathrm{C}, P<0.05)$. Milk progesterone was unaffected by treatment. In conclusion, the increased supply of $18: 3 n-3$ to the cows had only a modest effect on follicle populations and corpus luteum activity was unchanged.
\end{abstract}

linolenic acid / milk and plasma fatty acids / follicle growth / dairy cows

\section{INTRODUCTION}

Dairy cow fertility is low: first service conception rates are often below $50 \%$ and are declining regularly $(-0.5$ to $-1 \%$ per year $[1])$. Part of this decline is due to the increase in milk production and extended periods of negative energy balance observed post partum [2]. However, there has also been an evolution in the types of feeds given to dairy cows. Grass-based feeding systems (grass and grass silage), rich in 18:3n-3, have evolved towards cereal, by-products and maize silage-based systems, poor in 18:3n-3 and rich in 18:2n-6 [3]. Therefore the $n-6 / n-3$ ratio has increased over the years from around 0.5 up to 5-7.

Previous studies in cattle have shown that dietary fat can have a beneficial effect

\footnotetext{
* Corresponding author: aponter@vet-alfort.fr
} 
on reproductive function [4]. However, due to the varied nature of the fats used and variable rates of ruminal hydrogenation it is difficult to formulate a general theory to describe their mode of action. Improvements in pregnancy rate at $45 \mathrm{~d}$ post insemination [5], ovarian follicle growth [6] and steroidogenesis [7] have all been reported. It has been suggested that the mechanism involves enhanced ovarian activity through the following: improved energy status [8], increased availability of cholesterol for steroid synthesis [9] and increased circulating insulin concentrations [10].

Gong et al. [11] have shown that a diet which favours high plasma concentrations of insulin reduces the interval between calving and first ovulation compared to a control diet. In addition, it is known that unsaturated fatty acids (FA) are able to increase the concentrations of propionate produced in the rumen [12], which could increase both glucose production by the liver and insulin release from the pancreas. Rumen fermentation may be more strongly orientated towards propionate (insulin) production by a $18: 3 n-3$ supplement compared to a $18: 2 \mathrm{n}-6$ supplement since $18: 3 \mathrm{n}-3$ is more unsaturated than $18: 2 n-6$.

The positive effect of fat supplements on reproduction is further complicated by the fact that certain FA are precursors of prostaglandin (PG) synthesis. The FA precursors are liberated from phospholipid membranes and can then be converted to PG. The FA composition of the diet can affect the proportions of different FA in phospholipid membranes and therefore the type of PG produced. Staples et al. [4] have shown that the synthesis of $\mathrm{PGF}_{2 \alpha}$ is inhibited when dietary supplements of 18:3n-3 and 20:5n-3 are given, probably due to competition between the two substrates for the conversion enzymes $\left(\Delta^{6}\right.$ desaturase and cyclooxygenase) involved in PG synthesis. The opposite is true when a $18: 2 n-6$ rich supplement was given to pregnant ewes, both PGF2 $\alpha$ and its precursor, 20:4n-6, were increased in the caruncular endometrium
[13]. However, the same group [14] showed that in vitro $18: 2 n-6$ inhibited stimulated PGF $2 \alpha$ production by maternal endometrial cells as did a mixture of conjugated linoleic acids (CLA). Ward et al. [15] showed that a diet supplemented with $18: 2 n-6$ was more effective in increasing CLA than a diet supplemented with 18:3n-3, possibly because extra steps are required to produce CLA from $18: 3 n-3$ compared to $18: 2 n-6$ [16]. Therefore, the synthesis of series 2 PG could be affected in several ways.

In addition, 20:4n- 6 has been implicated in the acute regulation of steroid synthesis. Wang and Stocco [17] showed that 20:4n-6 increased the expression of steroidogenic acute regulatory protein (StAR). It is required for the transfer of cholesterol from the cytosol to the inner mitochondrial membrane, the rate limiting step for steroid synthesis, when trophic hormones increase steroid synthesis [18].

Therefore, if dairy cow feedstuffs are selected to improve the fatty acid (FA) composition of milk for human consumption, there may also be a favourable effect on reproduction by restoring the supply of $18: 3 n-3$ to those levels previously used. Current recommendations for FA consumption by humans are to reduce saturated fat intake and decrease the $n-6 / n-3$ ratio from 10 to 5 [19].

We hypothesise that a dietary supplement of 18:3n-3 improves ovarian follicle growth, possibly through higher insulin and glucose concentrations, and increases progesterone concentrations compared to a supplement rich in 18:2n-6.

\section{MATERIALS AND METHODS}

\subsection{Animals and diets}

Sixteen Holstein cows, requiring no assistance at calving, from the Experimental Farm at INA P-G, were studied. The cows used in the experiment were kept in one group in cubicle housing on slatted floors. Average cow weight was $645 \pm 21 \mathrm{~kg}$ at calving and 
2 primiparous and 14 multiparous cows were used in the experiment. The cows were milked twice daily at 06:00 $\mathrm{h}$ and 16:00 $\mathrm{h}$.

Following parturition, all the cows were given the same basal total mixed diet plus one of two supplements (control or linseed, Tab. I). The cows were allocated according to body condition score (BCS, scale 0 to 5; [20]) at calving, age and date of calving to one of the supplement groups: control, $2 \mathrm{~kg} \cdot \mathrm{d}^{-1}$ of extruded soybeans $(\mathrm{C}, n=8)$ or linseed, $2 \mathrm{~kg} \cdot \mathrm{d}^{-1}$ of extruded linseeds (L, $n=8$ ) (Tab. I). Extrusion was used to destroy any anti-nutritional factors found in the seeds. The extrusion method is covered by a patent [21]. Briefly, a single screw extruder was used to which an external source of water vapour was injected. The exit temperature was $120-130^{\circ} \mathrm{C}$. The seeds were ground ( $3 \mathrm{~mm}$ ) before being extruded. The supplements were given individually to the cows using an automatic concentrate distributor (Alpha Laval, France). Each time a cow entered the distributor its collar transponder was read by the machine and $500 \mathrm{~g}$ of one of the supplements were delivered into the trough in front of the cow up to a maximum of $2 \mathrm{~kg} \cdot \mathrm{d}^{-1}$. Table II gives the FA profiles of the feedstuffs. The basal diet was given ad libitum twice daily at 08:00 h and 16:00 h. Water and mineral fortified salt licks (containing: Na 370, Mg 3, Zn 9, $\mathrm{Mn} 7.5, \mathrm{Cu} 1.5, \mathrm{Fe} 0.4$, I 0.1, Co 0.06 and Se $0.015 \mathrm{mg} \cdot \mathrm{kg}^{-1}$ ) were available ad libitum throughout the experiment. One month after calving, oestrous cycles were synchronised (PRID $\left.{ }^{\circledR}[22]\right)$. Individual milk production and the amount of supplement given to each cow by the distributor were recorded on a daily basis. Milk samples were collected every two weeks at milking (morning and evening) for the measurement of milk fat and protein concentration (samples were pooled on a production basis before freezing and analysis). Body condition was noted at calving, at oestrus synchronisation and at the end of the experiment. For the experiment, the cows were selected to be thin $(2$ to $3 / 5)$ so that the mobilisation of body reserves would have little effect on the overall profile of circulating lipids. It has been shown that beef cows preferentially mobilise oleic acid compared to the other fatty acids [23]. All animals were cared for according to guidelines of the French Ministries of Agriculture and Fisheries, and Research.

\subsection{Blood and milk sampling}

Blood samples were collected weekly for nine weeks after calving by caudal venipuncture at midday. Blood was immediately centrifuged at $2000 \times g$ for $15 \mathrm{~min}$ at $4{ }^{\circ} \mathrm{C}$ after collection. Plasma was removed and stored at $-20^{\circ} \mathrm{C}$ until required for analysis. Milk samples were collected manually each week from all the cows for nine weeks after calving to measure the FA profile. The mammary gland was manually stimulated to encourage milk let-down and the first few $\mathrm{mL}$ were discarded. Milk samples were then collected from each quarter and pooled to give a composite milk sample for a cow. Milk was immediately frozen and stored at $-20{ }^{\circ} \mathrm{C}$ until required for analysis.

\subsection{Follicle growth and milk sampling}

Measurement of follicle growth was performed by the same operator (A.-E. Parsy) using a $7.5 \mathrm{MHz}$ ultrasonographic probe and a Dynamic Imaging ultrasonograph (Pie Medical, France). Each follicle was observed and an image was frozen on the screen of the ultrasonograph when it corresponded to the largest diameter. The follicle was then measured and the image printed. The numbers and the diameter of follicles were noted every $2 \mathrm{~d}$ starting from the day of PRID ${ }^{\circledR}$ removal. Milk samples were also collected at the same time as the ovaries were examined for the measurement of progesterone concentrations.

\subsection{Extraction and methylation of milk and plasma fatty acids and separation by gas chromatography}

Milk and plasma FA were extracted in $\mathrm{CHCl}_{3} / \mathrm{CH}_{3} \mathrm{OH}$ and converted to fatty acid methyl esters in a one step process as 
Table I. Composition and proximate analysis of the basal diet and supplements (Control or Linseed) given to dairy cows.

\begin{tabular}{|c|c|c|c|}
\hline & Basal diet & Control & Linseed \\
\hline \multicolumn{4}{|l|}{ Composition ( $\%$ dry matter): } \\
\hline Corn silage & 49.6 & & \\
\hline Wheat straw & 4.6 & & \\
\hline Sugar beet pulp silage & 8.5 & & \\
\hline Brewer dried grains & 7.9 & & \\
\hline Soybean meal & 15.9 & & \\
\hline Dehydrated alfalfa & 4.7 & & \\
\hline Hay & 7.5 & & \\
\hline Mineral and vitamin $\operatorname{mix}^{1}$ & 0.9 & & \\
\hline Sodium bicarbonate & 0.4 & & \\
\hline \multicolumn{4}{|l|}{ Composition $\left(\mathrm{g} \cdot \mathrm{kg}^{-1}\right.$ as fed): } \\
\hline Wheat bran & & 200.0 & 155.0 \\
\hline Sunflower meal & & 297.5 & 300.0 \\
\hline Soybean meal & & - & 185.0 \\
\hline Field peas & & - & 40.0 \\
\hline Molasses & & 40.0 & - \\
\hline Linseed & & - & 320.0 \\
\hline Soybean & & 432.5 & - \\
\hline Soybean oil & & 30.0 & - \\
\hline \multicolumn{4}{|l|}{ Nutrients ( $\mathrm{g} \cdot \mathrm{kg}^{-1}$ dry matter): } \\
\hline Net energy (kcal) & 1624 & 1983 & 1946 \\
\hline PDIN & 110 & 237 & 246 \\
\hline PDIE & 127 & 180 & 132 \\
\hline Fat & 27 & 144 & 142 \\
\hline Crude fibre & 189 & 164 & 166 \\
\hline Lignin & 30 & 82 & 91 \\
\hline Calcium & 7.9 & 7.9 & 8.8 \\
\hline Phosphorus & 4.4 & 3.9 & 2.6 \\
\hline n-3 PUFA & 29 & 26 & 139 \\
\hline n-6 PUFA & 168 & 138 & 52 \\
\hline Ratio n-6:n-3 & 5.79 & 5.31 & 0.37 \\
\hline
\end{tabular}

${ }^{1}$ Contained $\left(\mathrm{mg} \cdot \mathrm{kg}^{-1}\right)$ : Fe 100, Zn 100, Cu 20, Mn 40, Co 2, I 1, retinol 3, cholecalciferol 0.05, dl- $\alpha$-tocopherol acetate 20 , phytylmenoquinone 1 , thiamin 2 , riboflavin 10 , calcium pantothenate 20 , pyridoxine 10 , niacin 30, ascorbic acid 40, biotin (1\%) 0.2, cyanocobalamin 0.05 and choline 800 .

described previously [24]. The methylated fatty acids were separated by gas chromatography using a Shimadzu GC-17A with an automatic injector as previously described [23]. Individual weekly samples of milk and plasma from each cow were analysed.

\subsection{Analyses}

The nutrition values of the basal mixed diet and the supplements were estimated using equations [3] based on chemical composition measured using methods approved by the Association Française de Normalisation and the European Commission [3]. Plasma venous immunoreactive insulin was measured in a single assay using a double-antibody radioimmunoassay technique (INSI-PR, Cis Bio International, Gif-sur-Yvette, France) and glucose (Biomérieux, France), non-esterified fatty acids (NEFA, C 46551, Wako 
Table II. Fatty acid composition of the basal diet and supplements (Control or Linseed) (wt. \% of fatty acids) given to dairy cows ${ }^{\mathrm{a}}$.

\begin{tabular}{lccc}
\hline Fatty acid & Basal diet & Control & Linseed \\
\hline C10:0 & 4.8 & 1.4 & 1.5 \\
C12:0 & 1.2 & 1.0 & 1.0 \\
C15:0 & 3.4 & - & - \\
C15:1n-5 & 5.9 & - & - \\
C16:0 & 12.7 & 7.5 & 4.2 \\
C17:0 & 1.4 & - & - \\
C18:0 & 1.9 & 4.0 & 2.6 \\
C18:1n-9 & 13.1 & 20.3 & 16.5 \\
C18:2n-6 & 44.9 & 54.6 & 20.3 \\
C18:3n-3 & 7.7 & 10.1 & 53.6 \\
\hline
\end{tabular}

a Only fatty acids representing more than $1 \%$ of the total are presented.

Chemicals, Germany) and urea (Biomérieux, France) were analysed by photometric methods as previously described [23]. Corpus luteum activity was estimated by the measurement of milk progesterone concentrations. Progesterone was measured by EIA (Enzymun-Test progesterone, Roche Diagnostics, Meylan, France) on a clinical analyser (Elecys 1010, Roche Diagnostics, Meylan, France). The inter-assay coefficient of variation was $5.8 \%$ at $6.35 \mathrm{ng} \cdot \mathrm{mL}^{-1}$. The sensitivity of the assay was $0.03 \mathrm{ng} \cdot \mathrm{mL}^{-1}$.

\subsection{Statistical analysis}

The SAS [25] package was used to perform the statistical analyses. A multivariate repeated analysis [26] was used testing diet, time, and diet by time interaction on plasma insulin, glucose, NEFA, urea, body condition score, milk production, milk fat and protein levels, milk fat and protein secretion, milk and plasma fatty acid profiles and ovarian follicle growth. To analyse follicle growth, the follicles were classified into three groups: small follicles $(<5 \mathrm{~mm})$, medium follicles $(5-10 \mathrm{~mm})$ and large follicles $(>10 \mathrm{~mm})$ before being analysed by a multivariate repeated analysis testing the effects of diet, time, and diet by time inter- action. LS means \pm pooled SEM values are presented in the paper. A $P<0.05$ was considered to be statistically significant.

\section{RESULTS}

\subsection{Milk production and body condition score}

The level of milk production was unaffected by dietary treatment (L, $35.2 \pm$ $2.0 \mathrm{~kg} \cdot \mathrm{d}^{-1}$ vs. $\left.\mathrm{C}, 38.1 \pm 2.1 \mathrm{~kg} \cdot \mathrm{d}^{-1}\right)$ and increased with time during the experiment $(P<0.001)$. The fat content of milk was unaffected by the diet $\left(\mathrm{L}, 39.4 \pm 1.2 \mathrm{~g} \cdot \mathrm{kg}^{-1}\right.$ vs. C, $\left.41.0 \pm 1.4 \mathrm{~g} \cdot \mathrm{kg}^{-1}\right)$. Dietary treatment did not influence the protein content of milk $\left(\mathrm{L}, 27.7 \pm 0.5 \mathrm{~g} \cdot \mathrm{kg}^{-1}\right.$ vs. C, $\left.28.9 \pm 0.6 \mathrm{~g} \cdot \mathrm{kg}^{-1}\right)$. The quantities of fat and protein secreted by the cows were not affected by dietary treatment $\left(\mathrm{L}, 1357 \pm 93.6 \mathrm{~g} \cdot \mathrm{d}^{-1}\right.$ vs. C, $1545 \pm$ $100.5 \mathrm{~g} \cdot \mathrm{d}^{-1}$ and $\mathrm{L}, 977 \pm 63.8 \mathrm{~g} \cdot \mathrm{d}^{-1}$ vs. C, $1108 \pm 68.5 \mathrm{~g} \cdot \mathrm{d}^{-1}$ respectively). Both variables decreased with time $(P<0.01$ and $P<$ 0.05 respectively).

There was no significant difference between cows in the two dietary groups for BCS at the start of the experiment (L, 2.4 \pm 0.19 vs. C, $2.0 \pm 0.19)$. At the end of the experiment, the L cows had a lower body condition score $(1.1 \pm 0.19)$ than the C cows $(1.6 \pm 0.20$, interaction diet by time $P<0.01)$.

\subsection{Weekly analyses}

There was no significant effect of dietary regimen on plasma insulin, glucose and urea concentrations during the experiment (Tab. III). Plasma NEFA concentrations tended to be higher in L compared to $C$ cows $(P=0.08)$. The levels of insulin and urea increased with time $(P<0.01)$ while those of NEFA decreased $(P<0.01)$ during the experiment.

The average proportions of FA in milk over the experimental period are given in Figure 1. The milk FA, 4:0, 6:0 and 8:0 could not be separated by the column used so a pooled value is given in the results. The 
Table III. Effect of supplement (Control $(n=8)$ or Linseed $(n=8))$ on the evolution in plasma insulin, glucose, urea and non-esterified fatty acids in dairy cows.

\begin{tabular}{|c|c|c|c|c|c|c|c|c|c|c|c|}
\hline $\begin{array}{l}\text { Week } \\
\text { post partum }\end{array}$ & 1 & 2 & 3 & 4 & 5 & 6 & 7 & 8 & 9 & SEM & $\begin{array}{c}P \\
\text { value }\end{array}$ \\
\hline \multicolumn{12}{|c|}{ Insulin $\left(\mathrm{pmol} \cdot \mathrm{L}^{-1}\right)$} \\
\hline Control & 108.1 & 105.2 & 116.4 & 108.9 & 130.4 & 128.3 & 135.7 & 153.1 & 164.6 & 14.6 & $\mathrm{~T}^{* *}$ \\
\hline Linseed & 88.8 & 98.1 & 97.6 & 118.2 & 122.4 & 124.0 & 136.2 & 145.8 & 132.9 & 14.0 & \\
\hline \multicolumn{12}{|c|}{ Glucose $\left(\mathrm{mmol} \cdot \mathrm{L}^{-1}\right)$} \\
\hline Control & 2.78 & 2.61 & 2.61 & 2.53 & 2.65 & 2.72 & 2.70 & 2.70 & 2.83 & 0.16 & NS \\
\hline Linseed & 2.73 & 2.55 & 2.64 & 2.62 & 2.57 & 2.60 & 2.78 & 2.72 & 2.90 & 0.15 & \\
\hline \multicolumn{12}{|c|}{ Urea $\left(\mathrm{mmol} \cdot \mathrm{L}^{-1}\right)$} \\
\hline Control & 4.67 & 5.59 & 5.86 & 6.42 & 5.95 & 6.31 & 6.19 & 7.09 & 7.13 & 0.59 & $\mathrm{~T}^{* *}$ \\
\hline Linseed & 4.54 & 6.15 & 5.80 & 6.38 & 6.36 & 6.70 & 6.71 & 5.89 & 6.95 & 0.56 & \\
\hline \multicolumn{12}{|c|}{$\mathrm{NEFA}^{\mathrm{a}}\left(\mathrm{mmol} \cdot \mathrm{L}^{-1}\right)$} \\
\hline Control & 0.48 & 0.28 & 0.22 & 0.20 & 0.26 & 0.18 & 0.15 & 0.15 & 0.13 & 0.05 & $\mathrm{D}+$ \\
\hline Linseed & 0.58 & 0.41 & 0.32 & 0.23 & 0.26 & 0.34 & 0.19 & 0.18 & 0.16 & 0.05 & $\mathrm{~T}^{* *}$ \\
\hline
\end{tabular}

$\mathrm{D}=$ diet effect, $\mathrm{T}=$ time effect $\mathrm{NS}=$ non significant difference, $+P<0.10$, $* * P<0.01$.

a NEFA $=$ non-esterified fatty acids

proportions of 11:0 and 18:3n-3 were higher $(P<0.05$ and $P<0.001)$ in $\mathrm{L}$ than in $C$ cows. The proportions of $16: 1 \mathrm{n}-9$, 17:0, 17:1n-9, 18:1n-9 and 24:0 in the milk decreased with time $(P<0.001)$, while the proportions of $14: 0,14: 1 \mathrm{n}-9,16: 0$ and 18:3n-3 increased $(P<0.05)$. However, for $18: 3 n-3$ there was a diet by time interaction (Fig. 2) $(P<0.001)$, where the difference between the cows fed the two supplements increased with time $(\mathrm{L}>\mathrm{C})$.

The average proportions of some FA in plasma were affected by the supplements during the experiment. At the end of the experimental period the proportions of 18:0 were on average higher in L cows than in $\mathrm{C}$ cows $(23.4 \pm 1.4 \%$ vs. $18.2 \pm 1.5 \%, P<$ 0.01 ), while the proportions of $18: 1 \mathrm{n}-9$ and 18:2n-6 were on average lower with $\mathrm{L}$ compared to $\mathrm{C}(15.8 \pm 1.2 \%$ vs. $19.3 \pm 1.3 \%, P<$ 0.05 and $31.2 \pm 2.1 \%$ vs. $37.3 \pm 2.2 \%, P<$ 0.001 , respectively). There was an interaction supplement by time for 18:3n-3 $(P<$ $0.05)$, in L cows, the proportion of $18: 3 n-3$ in the plasma remained constant $(6.0 \pm$ $0.7 \%$ and $6.2 \pm 0.7 \%$, first and last sample) while the proportion decreased with time in C cows $(6.7 \pm 0.7 \%$ and $3.4 \pm 0.7 \%$, first and last sample).

\subsection{Reproduction data}

After the synchronisation protocol, oestrus behaviour was observed in $6 / 8$ and $7 / 8$ cows ( $\mathrm{L}$ and $\mathrm{C}$ respectively). Milk progesterone concentrations were unaffected by dietary treatment $\left(\mathrm{L}, 3.7 \pm 0.8 \mathrm{ng} \cdot \mathrm{mL}^{-1}\right.$ vs. C, $4.1 \pm$ $\left.0.8 \mathrm{ng} \cdot \mathrm{mL}^{-1}, P>0.05\right)$. Measurement of the number of follicles on the ovaries of the cows during the period after PRID $^{\circledR}$ removal showed that there was an effect of dietary treatment on the number of small follicles ( $<5 \mathrm{~mm}$, Fig. 3a), at $10 \mathrm{~d}(\mathrm{~L}<\mathrm{C}, P<0.05)$ and $24 \mathrm{~d}(\mathrm{~L}<\mathrm{C}, P<0.05)$ while, the number of medium $(5-10 \mathrm{~mm})$ and large $(>10 \mathrm{~mm})$ sized follicles was not affected by dietary treatment (Figs. 3b and 3c).

\section{DISCUSSION}

\subsection{Milk production and weekly blood measurements}

Milk production characteristics were not deteriorated by the use of the L compared to the $C$ supplement [27]. As has previously been observed, the concentrations of insulin [6] and urea increased after calving. The 


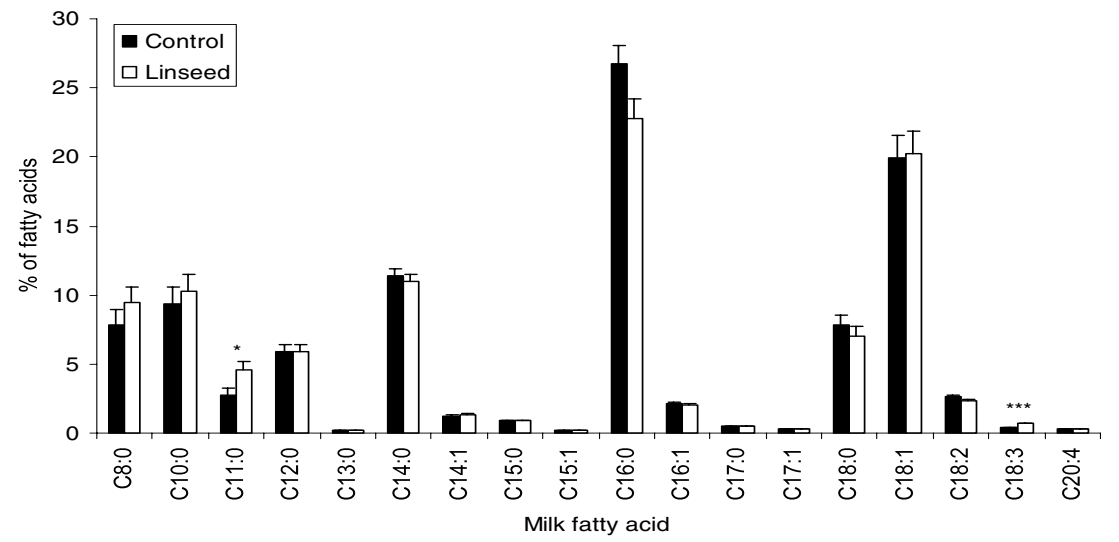

Figure 1. Effect of supplement ( $\square$ : Control $(n=8), \square$ : Linseed $(n=8))$ on average milk fatty acids $(\%)$ during the post partum period in dairy cows. Least-squares mean values with pooled standard error bars. $* P<0.05$ and $* * * P<0.001$

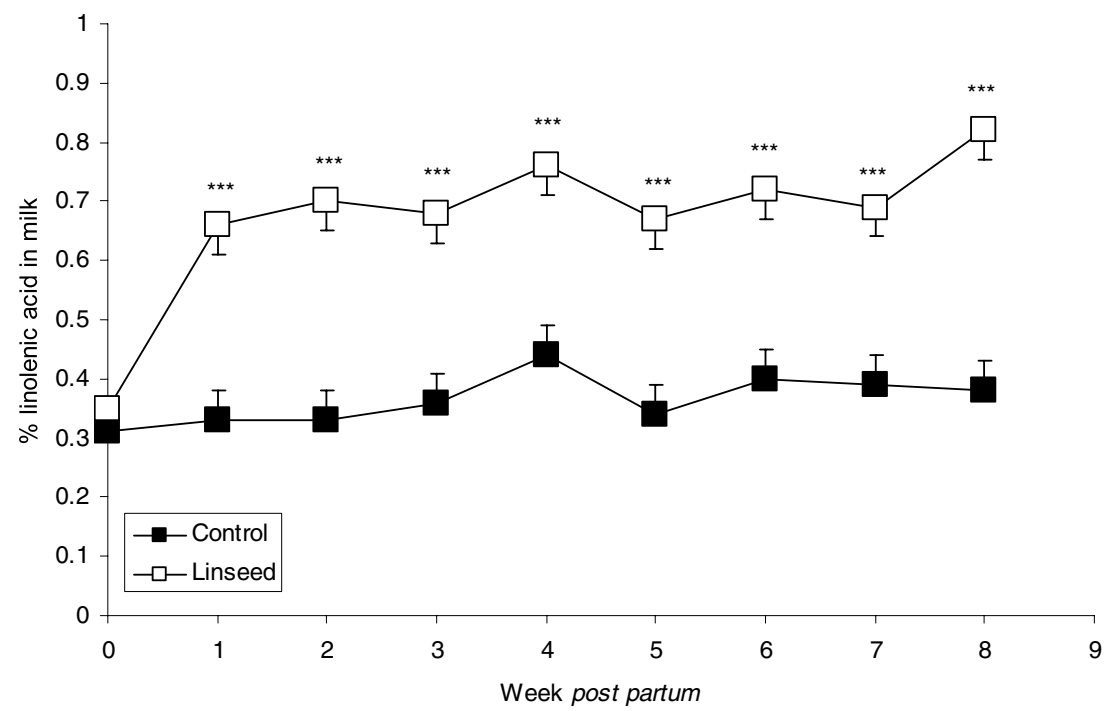

Figure 2. Effect of supplement ( $\boldsymbol{\square}$ : Control $(n=8), \square$ : Linseed $(n=8))$ on proportions of linolenic acid in milk. Least-squares mean values with pooled standard error bars. $* * * P<0.001$.

increase was initially slow, 0 to 3 wk post partum thereafter it was more rapid. An increased feed intake as lactation progresses [28] could explain why plasma insulin and urea increased with time post partum. The only difference observed between dietary treatments was the trend for a difference between the NEFA concentrations $(\mathrm{L}>\mathrm{C}$,
$P<0.10)$. NEFA increase when mobilisation of body lipids occurs [29]. Our results suggest that the L cows mobilised their adipose tissue reserves more than the $\mathrm{C}$ cows. This was confirmed by the interaction supplement by time observed for BCS, where L cows lost more body condition score than $\mathrm{C}$ cows over the experimental period. Since 

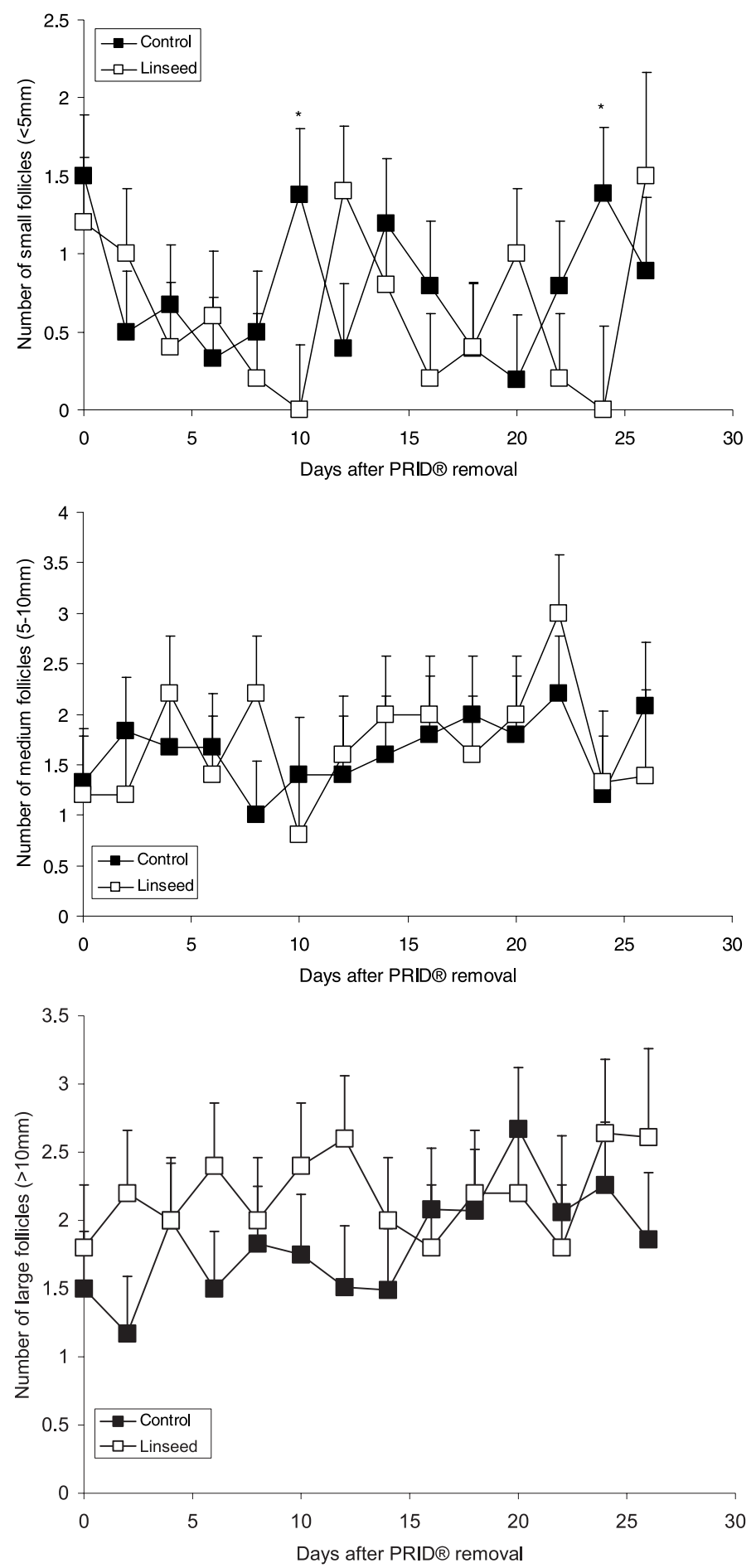
milk production characteristics were not different, it suggests that the L cows may have ingested less of the basal total mixed diet than the $\mathrm{C}$ cows.

\subsection{Fatty acid proportions in plasma and milk samples}

The proportions of $18: 3 n-3$ in plasma and in milk were multiplied by 1.4 and 2 respectively by the $\mathrm{L}$ compared to the $\mathrm{C}$ supplement confirming that the dietary treatment used to manipulate $18: 3 n-3$ supply to the cows was successful. However, the modification was relatively modest. With the concentrate alone, the L cows consumed $139 \mathrm{~g} \cdot \mathrm{d}^{-1}$ of $18: 3 \mathrm{n}-3$ and secreted $6.5 \mathrm{~g} \cdot \mathrm{d}^{-1}$ in milk while the $\mathrm{C}$ cows consumed $26 \mathrm{~g} \cdot \mathrm{d}^{-1}$ and secreted $3.3 \mathrm{~g} \cdot \mathrm{d}^{-1}$ in milk. There are several reasons for this finding. Firstly, it is well known that substantial hydrogenation occurs in the rumen [30] therefore, reducing the amount of polyunsaturated fatty acid which arrives in the small intestine for absorption. Secondly, Petit et al. [31] showed that when linseed oil is infused into the duodenum $(18: 3 n-3=$ $\left.270 \mathrm{~g} \cdot \mathrm{d}^{-1}\right)$ only $114 \mathrm{~g} \cdot \mathrm{d}^{-1}$ of $18: 3 \mathrm{n}-3$ was recovered in the milk. This indicates that a substantial part of 18:3n-3, even when supplied directly for absorption, is not transferred to milk fat.

\subsection{Follicle growth and progesterone concentrations}

In the present experiment we showed that $L(18: 3 n-3)$ only increased the numbers of small follicles compared to C (18:2n-6). In beef cows at maintenance, Thomas et al. [6] showed that a soybean oil supplement

Figure 3. Effect of supplement ( $\boldsymbol{\square}$ : Control $(n=$ 5), $\square$ : Linseed $(n=6)$ ) on the number of (a) small follicles $(<5 \mathrm{~mm})$, (b) medium follicles $(5-$ $10 \mathrm{~mm})$ and (c) large follicles $(>10 \mathrm{~mm})$ on the ovaries of dairy cows after the removal of a progesterone containing intra-vaginal device $\left(\right.$ PRID $\left.^{\circledR}\right)$. Least-squares mean values with pooled standard error bars. * $P<0.05$. was effective in increasing the number of medium sized follicles compared to a saturated fat (tallow) or a highly unsaturated fat (fish oil) supplement and this was associated with higher serum insulin. High insulin concentrations have been associated with increased granulosa cell proliferation [32] and improved follicle growth [11]. Thomas et al. [6] hypothesised that fermentation conditions in the rumen were modified and that more propionate was available for the soybean oil cows and this explained the higher insulin levels observed. Saturated FA (18:0) did not modify the acetate/propionate ratio in in vitro rumen fermentation [12] and highly unsaturated FA (fish oil) are relatively resistant to fermentation in the rumen [33]. Therefore, in the present experiment insulin levels were not modified differentially by dietary treatment because $18: 2 n-6$ and 18:3n-3 probably influenced the acetate/ propionate ratio to the same extent [12].

In the present experiment progesterone concentrations in milk were not affected by the dietary treatments. There appears to be a fundamental difference between the responses of cows fed marine lipids compared to those fed plant lipids. We believe that differences are centred on the supply of arachidonic acid to the uterus. There is no evidence that the uterus directly synthesises arachidonic acid [34] therefore, it is probably obtained from circulating lipids. The amount of arachidonic acid found in the blood depends on dietary intake and synthesis from linoleic acid in the liver. Feedstuffs (and adipose tissue reserves) contain very little arachidonic acid [35] and FA secretion (VLDL) by the ruminant liver is limited [36] especially in cows post partum. Therefore, linoleic acid taken up by the liver and converted to arachidonic acid may not be effectively released into the circulation. Zhang et al. [37] have shown that arachidonic acid accumulates in ovine endometrial tissue from late gestation to term and that it declines during lambing. In addition, Elmes et al. [13] have confirmed that the FA composition of the diet can affect the amount of 20:4n-6 accumulated 
in the uterus of pregnant ewes. Uterine arachidonic acid levels probably remain low in the early post partum period due to low intake and limited synthesis by the liver. When dairy cows are given fishmeal, arachidonic acid is replaced by long chain n-3 fatty acids in uterine phospholipids and this could reduce the amount of $\mathrm{PGF}_{2 \alpha}$ but not the amount of 3 series PG which can be synthesised [38]. When plant fatty acids (n-3 and n-6) are fed to dairy cows they may also displace arachidonic acid. Due to the lack of conversion of linoleic acid into arachidonic acid by the uterus [34], both linoleic acid and linolenic acid when incorporated into uterine phospholipids could inhibit all PG production because they are not direct precursors for PG (they need to be elongated and desaturated in the liver to be able to go on to form PG). This may explain the absence of a difference in stimulated PGFM concentrations in dairy cows given supplements of linolenic acid or linoleic acid [31, 39] compared to longer chain FA (fishmeal).

In conclusion, the metabolic particularities of dairy cows in the post partum period and the possible displacement of arachidonic acid by both linolenic and linoleic acids from uterine phospholipids may explain why the dietary supplements did not differentially alter progesterone profiles. There was only a minor effect of modifying the fatty acid profile of dietary lipids on follicle growth, with more small follicles in the 18:3n-3 supplemented cows compared to the $18: 2 n-6$ supplemented cows.

\section{ACKNOWLEDGEMENTS}

The authors would like to thank G. Victor and his team at the Ferme Expérimentale, Institut National Agronomique Paris-Grignon (INA P-G) for care of the animals, V. Bontems for help with sampling, and D. Rebours (VALOREX-PRODEX, France) for the gift of the feed supplements. Financial support for this work was provided by the Direction Générale de l'Enseignement et de la Recherche (DGER), France.

\section{REFERENCES}

[1] Pryce JE, Royal MD, Garnsworthy PC, Mao IL. Fertility in the high-producing dairy cow. Livest Prod Sci 2004, 86: 125-135.

[2] Butler WR, Smith RD. Interrelationships between energy balance and postpartum reproductive function in dairy cattle. J Dairy Sci 1989, 72: 767-773.

[3] AFZ-INRA Tables. Tables de composition et de valeur nutritive des matières premières destinées aux animaux d'élevage. Paris, INRA éditions, 2002.

[4] Staples CR, Burke JM, Thatcher WW. Influence of supplemental fat on reproductive tissues and performance of lactating cows. $\mathrm{J}$ Dairy Sci 1998, 81: 856-871.

[5] Burke JM, Staples CR, Risco CA, De La Sota RL, Thatcher WW. Effect of ruminant grade menhaden fish meal on reproductive and productive performance of lactating dairy cows. J Dairy Sci 1997, 80: 3386-3398.

[6] Thomas MG, Bao B, Williams GL. Dietary fats varying in their fatty acid composition differentially influence follicular growth in cows fed isoenergetic diets. J Anim Sci 1997, 75: 2512-2519.

[7] Oldick BS, Staples CR, Thatcher WW, Gyawu P. Abomasal infusion of glucose and fat - effect on digestion, production, and ovarian and uterine functions of cows. J Dairy Sci 1997, 80: 1315-1328.

[8] Hightshoe RB, Cochran RC, Corah LR, Kiracofe GH, Harmon DL, Perry RC. Effects of calcium soaps of fatty acids on postpartum reproductive function in beef cows. J Anim Sci 1991, 69: 4097-4103.

[9] Wehrman ME, Welsh TH, Williams GL. Dietinduced hyperlipidemia in cattle modifies the intrafollicular cholesterol environment, modulates ovarian follicular dynamics and hastens the onset of postpartum luteal activity. Biol Reprod 1991, 45: 514-522.

[10] Lammoglia MA, Willard ST, Hallford DM, Randel RD. Effects of dietary fat on follicular development and circulating concentrations of lipids, insulin, progesterone, estradiol-17 beta, 13,14-dihydro-15-keto-prostaglandin $\mathrm{F}_{2 \alpha}$, and growth hormone in estrous cyclic Brahman cows. J Anim Sci 1997, 75: 591-1600.

[11] Gong JG, Lee WJ, Garnsworthy PC, Webb R. Effect of dietary-induced increases in circulating insulin concentrations during the early postpartum period on reproductive function in dairy cows. Reproduction 2002, 123: 419-427.

[12] Elmes M, Tew P, Cheng Z, Kirkup SE, Abayasekara DRE, Calder PC, Hanson MA, Wathes DC, Burdge GC. The effect of dietary supplementation with linoleic acid to late gestation ewes on the fatty acid composition of 
maternal and fetal plasma and tissues and the synthetic capacity of the placenta for 2-series prostaglandins. Biochim Biophys Acta 2004, 1686: 139-147.

[13] Chalupa W, Rickabaugh B, Kronfeld DS, Sklan D. Rumen fermentation in vitro as influenced by long chain fatty acids. J Dairy Sci 1984, 67: 1439-1444.

[14] Cheng Z,Elmes M, Abayasekara DRE, Wathes DC. Effects of conjugated linoleic acid on prostaglandin production by cells isolated from maternal intercotyledonary endometrium, fetal allantochorion and amnion in late pregnant ewes. Biochim Biophys Acta 2003, 1633: 170-178.

[15] Ward AT, Wittenberg KM, Przybylski R. Bovine milk fatty acid profiles produced by feeding diets containing solin, flax and canola. J Dairy Sci 2002, 85: 1191-1196.

[16] Griinari JM, Bauman DE. Biosynthesis of conjugated linoleic acid and its incorporation into meat and milk in ruminants. In: Yurawecz MP, Mossoba MM, Kramer JKG, Pariza MW, Nelson GL (Eds.), Advances in conjugated linoleic acid research, Vol 1, Am Oil Chem Soc Press, Champaign, IL, 1999, p 180-200.

[17] Wang X, Stocco DM. Cyclic AMP and arachidonic acid: a tale of two pathways. Mol Cell Endocrinol 1999, 158: 7-12.

[18] Stocco DM, Clarke BJ. Regulation of acute production of steroids in steroidogenic cells. Endocr Rev 1996, 17: 211-244.

[19] Martin A. The "apports nutritionnels conseillés (ANC)" for the French population. Reprod Nutr Dev 2001, 41: 119-128.

[20] ITEB. Grille de notation de l'état d'engraissement des vaches Pie noires. Paris, éditions ITEB, 1985.

[21] Bulletin officiel de la Propriété Industrielle. Brevet d'invention, publication No 2808 971, delivered to Valorisation par Extrusion SA, France, by the Institut National de la Propriété Industrielle, France, 2003.

[22] Grimard B, Humblot P, Ponter AA, Chastant $S$, Constant F, Mialot J-P. Efficacité des traitements de synchronisation des chaleurs chez les bovins. INRA Prod Anim 2003, 16: 211227.

[23] Ponter AA, Douar C, Mialot J-P, BenoitValiergue H, Grimard B. Effect of underfeeding post-partum Charolais beef cows on composition of plasma non-esterified fatty acids. Anim Sci 2000, 71: 243-252.

[24] Sukhija PS, Palmquist DL. Rapid method for determination of total fatty acid content and composition of feedstuffs and feces. J Agric Food Chem 1988, 36: 1202-1206.

[25] SAS Version 8.2. Cary: SAS Institute Inc., 1999.

[26] Littell RC, Henry PR, Ammerman CB. Statistical analysis of repeated measures data using
SAS procedures. J Anim Sci 1998, 76: 12161231.

[27] Petit HV. Digestion, milk production, milk composition, and blood composition of dairy cows fed whole flaxseed. J Dairy Sci 2002, 85 : 1482-1490.

[28] Hoden A, Coulon J-B, Faverdin P. Alimentation des vaches laitières. In: Jarrige $\mathrm{R}$ (Ed.), Alimentation des bovines, ovins et caprins, Paris, INRA, 1988, p 135-158.

[29] Roberts CJ, Reid IM, Rowlands GJ, Patterson A. A fat mobilisation syndrome in dairy cows in early lactation. Vet Rec 1981, 108: 7-9.

[30] Moate PJ, Chalupa W, Jenkins TC, Boston RC. A model to describe ruminal metabolism and intestinal absorption of long chain fatty acids. Anim Feed Sci Tech 2004, 112: 79105.

[31] Petit HV, Dewhurst RJ, Scollan ND, Proulx JG, Khalid M, Haresign W, Twagiramungu $H$, Mann GE. Milk production and composition, ovarian function, and prostaglandin secretion of dairy cows fed omega-3 fats. J Dairy Sci 2002, 85: 889-899.

[32] Poretsky L, Kalin MF. The gonadotropic function of insulin. Endocr Rev 1987, 8: 132-139.

[33] Chow TT, Fievez V, Moloney AP, Raes K, Demeyer D, De Smet S. Effect of fish oil on in vitro rumen lipolysis, apparent biohydrogenation of linoleic and linolenic acid and accumulation of biohydrogenation intermediates. Anim Feed Sci Technol 2004, 117: 1-12.

[34] Mattos R, Staples CR, Thatcher WW. Effects of dietary fatty acids on reproduction in ruminants. Rev Reprod 2000, 5: 38-45.

[35] Christie WW. The effects of diet and other factors on the lipid composition of ruminant tissues and milk. In: Christie WW (Ed.), Lipid metabolism in ruminant animals, Oxford, Pergamon Press Ltd, 1981, p 193-226.

[36] Emery RS, Liesman JS, Herdt TH. Metabolism of long chain fatty acids by ruminant liver. J Nutr 1992, 122: 832-837.

[37] Zhang Q, Wu WX, Nathanielsz PW, Brenna JT. Distribution of arachidonic, eicosapentaenoic, docosahexaenoic and related fatty acids in ovine endometrial phospholipids in late gestation and labor. Prostaglandins Leukot Essent Fat Acids 1995, 53: 201-209.

[38] Abayasekara DRE, Wathes DC. Effects of altering dietary fatty acid composition on prostaglandin synthesis and fertility. Prostaglandins Leukot Essent Fat Acids 1999, 61: 275-287.

[39] Robinson RS, Pushpakumara PGA, Cheng Z, Peters AR, Abayasekara DRE, Wathes DC. Effects of dietary polyunsaturated fatty acids on ovarian and uterine function in lactating dairy cows. Reprod 2002, 124: 119-131. 